Research Report No. 12/2011

\title{
Harmonizing Through Judicial Review: Statutory Interpretation and Participation in Sub-Arctic Resource Management
}

Sari M. Graben

Follow this and additional works at: http:/ / digitalcommons.osgoode.yorku.ca/clpe

\section{Recommended Citation}

Graben, Sari M., "Harmonizing Through Judicial Review: Statutory Interpretation and Participation in Sub-Arctic Resource Management" (2011). Comparative Research in Law \& Political Economy. Research Paper No. 12/2011.

http://digitalcommons.osgoode.yorku.ca/clpe/50 


\section{OSGOODE}

OSCOODE HALL LAW SCHOOL

YOR K UNIVERSITY

\section{OSGOODE HALL LAW SCHOOL}

Comparative Research in Law \& Political Economy

RESEARCH PAPER SERIES

Research Paper No. 12/2011

\section{Harmonizing Through Judicial Review: Statutory Interpretation and Participation in Sub-Arctic Resource Management}

Sari M. Graben

Editors:

Peer Zumbansen (Osgoode Hall Law School, Toronto, Director, Comparative Research in Law and Political Economy) John W. Cioffi (University of California at Riverside) Lisa Philipps (Osgoode Hall Law School, Associate Dean Research) Nassim Nasser (Osgoode Hall Law School, Toronto, Production Editor) 
Osgoode CLPE Research Paper 12/2011

Vol. 07 No. 04 (2011)

Sari M. Graben

\title{
Harmonizing Through Judicial Review: Statutory Interpretation and Participation in Sub-Arctic Resource Management
}

\begin{abstract}
This article describes how statutory interpretation by the courts can impact the effectiveness of co-management initiatives in Canada. Canada has recently undertaken a massive restructuring of the administrative regimes that license and permit resource development across the country to better incorporate Indigenous participation. These comanagement boards now take part in governing resource use across Canada and most recognizably in parts of British Columbia, the Yukon Territories, the Northwest Territories and Nunavut. Nevertheless, the degree to which Indigenous participation may impact the regulatory output of co-management boards remains uncertain in law. This article uses one comanagement statute in Canada, the Mackenzie Valley Resource Management Act, to explore the complexities of accounting for participation in resource management in the sub-Arctic. The article argues that construction by the courts of the Mackenzie Valley Resource Management Act as similar to its predecessor, the Canadian Environmental Assessment Act, has the effect of construing the former statute as a procedural tool, which effectively divorces participation from the regulatory output of co-management boards. While by no means settled, this trend towards participation as a procedure of co-management is construed from a reading of the legislation as a legal transplant and its concomitant harmonization by the court with other statutory schemes. This article thus analyzes how the effectiveness of co-management is impacted by assumptions that the meaning of law can remain unaltered despite stakeholder participation.
\end{abstract}

Keywords: Law, Regulation, Participation, Co-Management, Indigenous, Arctic, Environment, Resource Management, Transplant, Statutory Interpretation, Judicial Review

JEL Classification: K23, K32, K12, D73, D74, D78, O20, Q56

Sari M. Graben

Post-Doctoral Fellow

Queen's Institute for Energy and Environmental Policy

School of Policy Studies, Queen's University

138 Union St.

Kingston Ontario

K7L 3N6

Email:sari.graben@queensu.ca 


\title{
Harmonizing Through Judicial Review: Statutory Interpretation and Participation in Sub-Arctic Resource Management
}

\author{
Sari M. Graben ${ }^{1}$
}

\section{INTRODUCTION}

To tell a story about the role of law in constructing and governing co-management boards involves telling the story of participation. Co-management is increasingly important as a mechanism for resource management by Indigenous peoples across Canada. As de-centered bodies for shared decision-making, co-management replaces highly centralized regimes, which involve little participation by Indigenous peoples in licensing and permitting. The statutes that underpin co-management regimes vary in accordance with the types of arrangements established. However, those regimes established pursuant to contemporary land claims (i.e. those concluded with the Gwich'in, the Sahtu, the Tlicho, and the Inuvialuit in the Northwest Territories, the Inuit of Nunavut, and the Nisga'a in British Columbia) have been established as institutions of public government. ${ }^{2}$ These agencies now license most undertakings related to the use of land, water, and wildlife in their respective regions. While there are significant differences among them, all of the statutory arrangements reflect a shared commitment to the increased participation of Indigenous stakeholders in regulatory decision-making. This is the story of one such statutory arrangement.

In 1998, the Mackenzie Valley Resource Management Act (MVRMA) established a number of resource management boards tasked with regulating resource development in the Mackenzie Valley. ${ }^{3}$ The MVRMA was established pursuant to and in accordance with several contemporary treaties. With some exceptions, its jurisdiction applies to the Northwest Territories and includes five regions governed by the Gwich'in, Sahtu, Deh Cho, Akaitcho and Tlicho or Wek'eezhi peoples. As a federal statute, its purpose is to provide for an integrated system of land and water management in the Mackenzie Valley and to establish certain boards for that purpose. ${ }^{4}$ As such, the MVRMA establishes a number of regulatory boards and vests them with permitting authority over land and water in the settlement areas.

\footnotetext{
*Post-Doctoral Fellow, Queen's Institute for Energy and Environmental Policy, School of Policy Studies, Queen's University, 138 Union St., Kingston Ontario, K7L 3N6. Email:sari.graben@queensu.ca

${ }^{2}$ Gwich'in Land Claim Settlement Act, SC 1992, c 53, Sahtu Dene and Metis Land Claim Settlement Act, SC 1994, c 27, Tlicho Land Claims and Self-Government Act, SC 2005, c 1, Western Arctic (Inuvialuit) Claims Settlement Act, SC 1984, c 24), Nunavut Land Claims Agreement Act SC 1993, c 29, Nunavut Waters and Nunavut Surface Rights Tribunal Act SC 2002, c 10, and Nisga'a Final Agreement Act, SC 2000, c 7.

${ }^{3}$ Mackenzie Valley Resource Management Act, SC 1998, c 25 [MVRMA].

${ }^{4}$ MVRMA, Purpose Statement.
} 
The MVRMA is set out in seven parts. Part 1 sets out general provisions respecting all of the boards within its purview. Parts 2 to 5 establish particular boards related to land use planning, land and water regulation, and environmental impact review. Part 6 establishes environmental monitoring and audit requirements and Part 7 deals with implementation and amendment. The effect of the MVRMA is to establish a land use planning board and a land and water board for each of the three settlement areas. For overlapping jurisdictional issues, it establishes the Mackenzie Valley Land and Water Board and all environmental impact assessment is routed through the Mackenzie Valley Environmental Impact Review Board (the Review Board). In short, any development that requires the use of land or water must go through at least one of the permitting boards and, if needed, an environmental assessment.

While each of these boards regulates particular resources, as a whole, the MVRMA reflects a broader shift to co-management as a form of participatory governance. ${ }^{5}$ In Canada, comanagement arrangements are decision-making bodies that comprise nominees of Indigenous and non-Indigenous governments. Formed as an alternative to centralized decision-making prototypical of resource management, it is a model for shared decision-making that uses the direct participation of effected citizens. It bolsters public participatory procedures that are meant to legitimate public administration, but which can have the effect of excluding or silencing particular kinds of marginalized communities. ${ }^{6}$ Despite the existence of procedural avenues to participate in hearings and make submissions, these avenues were either not used or used to little effect. ${ }^{7}$

\footnotetext{
${ }^{5}$ For a comparison of co-management and participatory governance see Sari Graben, "Writing the Rules of SocioEconomic Assessment, Adaptation Through Participation" available at http://papers.ssrn.com/sol3/papers.cfm?abstract id=1628156 . For a discussion of co-management, see Stephen R. Tyler, In_Focus: Comanagement of Natural Resources Local Learning For Poverty Reduction (Ottawa: IDRC, 2006).

${ }^{6}$ Iris M. Young, Justice and the Politics of Difference (Princeton, New Jersey: Princeton University Press, 1990).

${ }^{7}$ In many ways, this confirms similar scholarship that argues that Indigenous participation in the state's legal institutions has not necessarily resulted in the incorporation of Indigenous perspectives on the law. For examples of these accounts, see James S.Y. Henderson, Indigenous Jurisprudence and Indigenous Rights, Defining a Just Society (Saskatoon: Native Law Centre, University of Saskatchewan, 2006) at 128-177. Also see H. Cardinal \& W. Hildebrandt, Treaty Elders of Saskatchewan: Our Dream is That Our People Will One Day be Clearly Recognized as Nations (Calgary: University of Calgary Press, 2000), Menno Boldt, Anthony J. Long \& Leroy Little Bear, The Quest for Justice: Indigenous Peoples and Indigenous Rights (Toronto: University of Toronto Press, 1985) and, Leroy Little Bear, Menno Boldt, \& Anthony J. Long, eds, Pathways to Self-Determination: Canadian Indians and the Canadian State (Toronto: University of Toronto Press, 1984). In the administrative realm, see Catherine Bell, \& David Kahane, eds, Intercultural Dispute Resolution in Aboriginal Contexts (Vancouver: UBC Press, 2004), Lorne Sossin, 'The Duty to Consult and Accommodate: Procedural Justice as Aboriginal Rights' (2010) 23:1 Canadian Journal of Administrative Law and Practice 93; David Mullan, 'The Duty to Consult Aboriginal Peoples - The Canadian Example' (2009) 22:2 Canadian Journal of Administrative Law and Practice 107.
} 
What is challenging about the MVRMA is that it does not explicitly state substantive goals for participation. To be sure, the MVRMA incorporates a number of unique provisions meant to promote Indigenous participation in resource management. For example, the most well known participatory provisions pertain to the membership requirements for the boards. Additionally, there are provisions that cite the relevance of treaties, the creation of the boards, the consideration of Traditional Knowledge, the assessment of socio-economic impacts, and the requirement to consult with Indigenous governments. ${ }^{8}$

In spite of these provisions, the statute does not state what purpose these participatory provisions are meant to achieve in decision-making. Instead, the relationship between the ends and means of the MVRMA, as it relates to participation, are to be inferred. For example, the MVRMA states that one of the Review Board's purposes is to ensure that the concerns of Aboriginal people and the public are taken into account. ${ }^{9}$ However, procedures for public participation generally require agencies to consider public concerns and Indigenous peoples are part of that public. Consequently, these types of provisions provide little insight into how Indigenous participation could result in regulatory decisions that are different from any other agency. Rather, the uncertain relationship between participation and regulatory decisionmaking leaves the impact of these provisions unclear.

In an attempt to unpack the purpose of participation in the MVRMA, Part II of this article will introduce the policy objectives of the MVRMA as documented by the large political literature on co-management in Canada. Linking participation with the achievement of power sharing and better resource management, this section argues that the MVRMA intends to use participation as a technique for the achievement of these goals. This reading of the MVRMA derives from its roots in the political movement for self-government and resource management. Part III builds on the finding that participation is a technique of the MVRMA, aimed at achieving certain policy objectives, to ask whether the MVRMA operates effectively. Drawing on insights from the critical scholarship on transplants and recent judicial treatment, this section argues that implementing legal norms that result from participation can be problematic for the courts. Rather than consider how the participatory provisions impact a reading of the MVRMA, the trend to harmonization constructs meaning as defined by the Federal government.

Drawing on the seeming disconnect between participation and statutory interpretation, Part IV argues for a cautious reading of the MVRMA as supportive of effective participation. Caution is recommended because the impetus to harmonize the meaning of the MVRMA with the CEAA can have the effect of limiting the potential for difference that can result from participation. The constraint on difference can limit the effect of those participatory provisions to procedural requirements, thereby disconnecting it from the policy objectives of co-management.

\footnotetext{
${ }^{8}$ Sari Graben, 'Establishing Participation in the Mackenzie Valley Resource Management Act' (on file with author).

${ }^{9}$ MVRMA, s 114 (c).
} 


\section{The Participatory Objectives of the MVRMA}

In order to understand the role of the MVRMA in achieving participation it is essential to return to the policy objectives of co-management more generally. While diverse, the policy objectives of co-management can be roughly broken down into two main objectives: the resolution of political conflicts between Indigenous peoples and state government through the restructuring of relations and better technical management of natural resources. ${ }^{10}$

As it relates to political conflict, Indigenous participation in co-management is expected to "resolve challenges to the legitimacy of state claims to management through redistributing rights and duties leading to greater community involvement in decision making." ${ }^{11}$ Although there are differences between scholars on co-management, many share the view that they are conduits for political participation. ${ }^{12}$ For example, Mulrennan and Scott see co-management institutions as remedying a history of power imbalance by preserving the rights and interests of Indigenous peoples in the land and sea resources through a sharing of power. ${ }^{13}$ To Mulrennan and Scott, power-sharing through co-management assists the project of decolonization, which premises conflicts over resources on principles of consent. Peter Usher sees co-management as remedying the more abstract conflicts between state and Indigenous systems of wildlife management by providing for power sharing between communities and government. ${ }^{14}$ Gary Kofinas advocates for systems that reflect culturally defined authority systems of property relations, practices, and beliefs affecting resources, resource users, and their greater community. ${ }^{15}$ Although there are some differences between these scholars, they each posit comanagement boards as conduits for political authority aimed at empowering Indigenous peoples.

\footnotetext{
${ }^{10}$ Natcher adds a third goal: recognize the knowledge and wisdom of aboriginal peoples. David Natcher, Susan Davis, \& Clifford G. Hickey 'Co-Management: Managing Relationships, Not Resources' (2005) 64:3 Human Organization 240 at 240.

${ }^{11}$ Joseph J. Spaeder, \& Harvey A. Feit. 'Co-management and Indigenous Communities: Barriers and Bridges to Decentralized Resource Management - Introduction' (2005) 47:2 Anthropologica 147.

${ }^{12}$ For examples see Monica E. Mulrennan, and Colin H. Scott, 'Co-management - An Attainable Partnership? Two Cases From James Bay, Northern Quebec and Torres Strait, Northern Queensland' (2005) 47:2 Anthropologica 197; Gary P. Kofinas, 'Caribou Hunters and Researchers at the Co-management Interface: Emergent Dilemmas and the Dynamics of Legitimacy in Power Sharing' (2005) 47:2 Anthopologica 179; Peter J. Usher, 'Contemporary Aboriginal Land, Resource and Environmental Regimes: Origins, Problems and Prospects' in For Seven Generations: An Information Legacy of the Royal Commission for Aboriginal Peoples CD-ROM. (Ottawa: Libraxus, 1997), Graham White, 'Cultures in Collision: Traditional Knowledge and Euro Canadian Governance Processes in Northern Land Claims Boards' (2006) 59:4 Arctic 401.

${ }^{13}$ Mulrennan \& Scott, supra note 11 at 198.

${ }^{14}$ Usher, supra note 11.

${ }^{15}$ Kofinas, supra note 11.
} 
Similarly, understanding the MVRMA as a deliberate effort to promote participation derives from its contextualization in contemporary treaty negotiation in the Mackenzie Valley. ${ }^{16}$ Starting in the 1970's, the Federal government began to pursue resource development in the region. ${ }^{17}$ Territorial political autonomy as a product of rights responded to this development and laid the groundwork for the creation of statutory institutions. Not only were the boards formed on the basis of rights recognition preceding the treaties. Those rights were then reformulated in treaty provisions delineating Indigenous representation on resource management boards. Thus, while the MVRMA does not itself delineate self-government, it is a part of the larger movement to actualize the conceptualization of Aboriginal rights to selfgovernment in Canada over the past 40 years. ${ }^{18}$ Seen in this context, the purpose of the MVRMA is to use innovative participatory techniques that allow Indigenous communities to share in decision-making. ${ }^{19}$

As it relates to improved management, Indigenous participation is expected to offer a greater base of knowledge with which to address the problem of unsustainable, ineffective, or unfair resource management regimes. ${ }^{20}$ Advocates expect that "more holistic insights into ecosystems dynamics would result from an integration of traditional and science based knowledge" and from devolution to local organizations. This expectation is mirrored in the MVMRA. For example, statutory provisions that permit reliance on Traditional Knowledge reinforce the power of the agencies to search out and use oral histories and elder testimonies as part of the evidentiary record. ${ }^{21}$ This use of Traditional knowledge expects it to alter regulation because of new information being transmitted by Indigenous participation.

What is important for the purposes of this article is that both of these objectives rely on the use of a procedural technique, Indigenous participation. The innovation of the MVRMA is that it incorporates participants who can presumably represent the knowledge of Indigenous peoples in the region. Thus, both objectives assume that having Indigenous persons make decisions will result in the achievement of better resource management and shared power. Through this

\footnotetext{
${ }^{16}$ For an argument that decentralized management is most effective for resource use see Leslie C. Gray, 'Decentralization, Land Policy and the Politics of Scale in Burkina Faso' in Karl Zimmerer, ed, Globalization \& New Geographies of Conservation (Chicago: University of Chicago Press, 2006) 277-295 at 277. For the Canadian context see the early work of Evelyn Pinkerton, ed, Co-operative Management of Local Fisheries: New Direction for Improved Management and Community Development (Vancouver: University of British Columbia Press, 1989).

17 Thomas Berger, Northern Frontier, Northern Homeland: The Report Of The Mackenzie Valley Pipeline Inquiry. (Vancouver: Douglas \& Mclntyre, 1988).

${ }^{18}$ For examples see supra note 11.

19 Paul Nadasdy, 'The Anti-Politics of TEK: The Institutionalization of Co-Management Discourse' (2005) 47(2) Anthropologica 215 at 216 [Nadasdy, 'Anti-Politics'].

${ }^{20}$ White, supra note 11.

${ }^{21}$ MVRMA, s 115.1, s 60.1(b), s 146, and s 150.
} 
reasoning, the substantive objectives of the MVRMA become enmeshed with the procedural ones and participation becomes a technique of regulation. ${ }^{22}$

For example, stakeholder participation is primarily achieved through the requirement that persons nominated by Indigenous governments constitute at least equal or majority membership on the boards. Each of the Indigenous governments in the region nominates or appoints members to the board. ${ }^{23}$ The territorial minister and federal government nominate the remaining members. This use of representative membership subverts the central tenet that centralized management is an appropriate tool for resource management in the Mackenzie Valley. Representation in co-management is directly related to regulatory interest. As might be expected, resource management representation is delineated in accordance with the type of rights an Indigenous government holds in relation to the land. Where the Indigenous government is thought to have a greater vested interest in the outcome, such as a project conducted on its fee simple land, it is granted greater representation on the boards. Where its interest is deemed lesser or is only one among other interested governments, its representation is lessened correspondingly. In short, the shifting composition of a board reflects an attempt to allocate board membership in accordance with an estimation of an Indigenous government's interest in the proposal.

Indigenous peoples have been identified in the common law as stakeholders in resource management and have used participatory processes to forward their claims. ${ }^{24}$ However, in contrast to participatory procedures common to the public at large, co-management allows Indigenous citizens to move beyond procedural rights and participate as decision-makers at multiple stages of regulation. ${ }^{25}$ Indigenous stakeholders do not merely have procedural rights to access relevant information, to make submissions on environmental decisions and to use courts to enforce consideration of their viewpoints. Instead, Indigenous peoples are now part of the institutions in which collective decisions are deliberated. Co-management offers participation in deliberation.

\footnotetext{
22 Julia Black 'Proceduralizing Regulation I' (2000) 20:4 Oxford Journal of Legal Studies 597 at 597 (describes procedures, participation and institutional design as the common solutions to perceived regulatory problems).

${ }^{23}$ Officially, the Federal minister appoints all members of the board and the Sahtu and Gwich'in each nominate their members for appointment. The notable exceptions are those members who are directly appointed by the Tlicho government, MVRMA s 11 (1), s 112 (1) (2) and (3).

${ }^{24}$ For example, Haida Nation v. British Columbia [2004] SCC 73 and Taku River Tlingit First Nation v. British Columbia [2004] SCC 74.

${ }^{25}$ Archon Fung and Erik O. Wright, Deepening Democracy: Innovations in Empowered Participatory Governance (London: Verso, 2003). Nadasdy, 'Anti Politics', supra note 118 at 216.
} 


\section{IMPLEMENTING PARTICIPATION}

If the resolution of political conflicts and better technical management are the objectives of comanagement and participation is the technique, the salient legal question is whether the MVRMA operates in a manner which promotes or prevents the realization of its objectives. The role which participation plays in the interpretation of the MVRMA has so far gone unexamined in the legal scholarship. However, both the transnational scholarship on legal transplants and some examples taken from recent cases provide some foresight that implementing legal norms that results from participation could be complicated for the courts, given the language and structure of the MVRMA.

\section{A. MVRMA AS TRANSPLANT}

A legal transplant is generally understood as a rule or system of law that has moved from one country to another. ${ }^{26}$ There are differences as to how the law moves, which arguably go to intention and impact. ${ }^{27}$ However, for immediate purposes, whether law is borrowed, ${ }^{28}$ diffused, ${ }^{29}$ irritates, ${ }^{30}$ or migrates, ${ }^{31}$ the law is transplanted beyond national boundaries. In addition to comparing legal systems, analyzing transplants can also include the comparison of legal cultures or traditions. ${ }^{32}$ The realization that there can be much variation between groups within a nation state has led to an interest in identifying smaller units of legal culture. ${ }^{33}$ This interest derives from the understanding that legal traditions illuminate whether formal laws and legal institutions of a legal system reflect the values and perspectives of those engaged by them. ${ }^{34}$

${ }^{26}$ Alan Watson, Legal Transplants: An Approach to Comparative Law, $2^{\text {nd }}$ ed (Athens, Georgia: The University of Georgia Press, 1993).

${ }^{27}$ For a discussion of the terms used to describe the process, see Esin Örücü, 'Law as Transposition' (2002) 51:2 International and Comparative Law Quarterly 205- 223.

${ }^{28}$ Watson, supra note 25.

${ }^{29}$ William Twining,. 'Social Science and Diffusion of Law' (2005) 32 Journal of Law and Sociology 203.

${ }^{30}$ Gunther Teubner, 'Legal Irritants, Good Faith in British Law or How Unifying Law Ends up in New Divergences' in Francis G. Snyder, ed, The Europeanisation of Law: The Legal Effects of European Integration (Oregon: Hart Publishing, 2000) 243.

${ }^{31}$ Sujit Choudry, The Migration of Constitutional Ideas (New York: Cambridge University Press, 2006).

32 Esin Örücü, 'Developing Comparative law' in E. Örücü and David Nelken, eds, Comparative Law: a Handbook (Oregon: Hart Publishing, 2007) 43 at 58. This can be contrasted with the 'Grands Systemes' approach at the macro level and the 'Country and Western' tradition at the micro level of private law. For discussion see William Twinning, Globalisation and Legal Theory (Cambridge: Cambridge University Press, 2000) 32.

33 David Nelken, 'Defining and Using the Concept of Legal Culture' in Esin Örücü and David Nelken, eds, Comparative Law: a Handbook, (Oregon: Hart Publishing, 2007) at 117.

${ }^{34}$ As Nelken writes, 'books about legal culture do not have the same starting point as those which describe a system's law in the books' Ibid at 117. 
Can the rules that govern co-management be treated as transplants? Co-management boards involve the application of legal norms that did not originate in Indigenous communities or reflect traditional Indigenous values. Instead, Boards operate in accordance with their constitutive statutes, treaties, and regulations. These norms are widely understood as originating from Federal legislative procedures and are premised on bureaucratic and scientific values. Consequently, there is sufficient evidence that the MVRMA is sufficiently distinct from Indigenous traditions to render the points in this literature relevant to this discussion on comanagement. ${ }^{35}$ Moreover, the use of transplant typologies to understand co-management builds on earlier recognition that European law was transplanted into North America in the 19th century but was not always applied to the Indigenous population. ${ }^{36}$ This has been especially true of Indigenous people residing in Northern Canada, where, up until WWII, federal law was less frequently applied or enforced. Because of these differences, the current legislative framework of co-management can be characterized as a legal system that was transplanted to the Mackenzie Valley. The following discussion addresses these differences in more detail.

\section{The Template: State Management}

Research on the MVRMA reveals its fundamental character to be that of a state management system. It derives its authority from the constitutional powers exercised by federal, and territorial legislatures or executives and follows Weberian principles of bureaucracy and rational inquiry. ${ }^{37}$ Peter Usher, a geographer with experience in co-management, provides a characterization of state management as premised on:

a common property concept in which the state assumes exclusive responsibility and capability for managing a resource equally accessible to all citizens. The state manages for certain levels of abundance on a technical basis, and then allocates shares of this abundance to users on an economic and political basis. The system of knowledge is based on a scientific accumulation, organization and interpretation of data and management problems are resolved in a technical, historical, framework. This system of management is bureaucratic (i.e.) hierarchically organized and vertically compartmentalized. Managers become distinct from harvesters, authority

\footnotetext{
${ }^{35}$ For a contrary view of Western legal traditions as distinctly different and changeable see Harold J. Berman, Law and Revolution: The Formation of the Western Legal Tradition (Cambridge: Harvard University Press, 1983).

${ }^{36}$ Daneil Berkowitz et al. 'Relationships Between Development, Legality and Transplants' 47 (2003) European Economic Review 165 at 173-175.

37 Harvey Feit 'Self-Management and State-management: Forms of Knowing and Managing Northern Wildlife in Traditional Knowledge and Renewable Resources Management in Northern Regions' Milton M.R. Freemand \& L.N. Carbyn, eds, Traditional Knowledge and Renewable Resources Management in Northern Regions Occasional Paper No. 20 (Edmonton: Boreal Institute for Northern Studies, 1988) 72. Also see Claudia Notske, Indigenous Peoples and Natural Resources in Canada. (Ontario: Captus University Publicationn, 1994) and Claudia Notske, 'A New Perspective in Indigenous Natural Resource Management: Co-management' 26:2 Geoforum 187.
} 
becomes centralized and flows from the top down. The environment is reduced to conceptually discrete components, which are managed separately. As these separate management units take on a life of their own, management objectives diverge and become focused on specialized objectives. $^{38}$

The first commonality between the MVRMA and state management is that the MVRMA vests exclusive authority for resource management in the state. Co-management boards are made up of governmental nominees of the Federal, Territorial, and Indigenous governments. Each is connected through a network of complex governmental relations set out in the contemporary treaties. While boards are independent agencies, they are a product of statute and connected to the government through various bureaucratic channels. Moreover, the Review Board provides recommendations to the Minister of Indian and Northern Affairs, who has final decision-making power over permitting. Within the MVRMA, the state, albeit encompassing a broader range of decentralized institutions, most definitely assumes exclusive responsibility and capability for managing resources in the region.

Other common features are that the language of the MVRMA relies on technical and scientific knowledge. It is notable that similar to other statutes in Canada there is a provision for seeking out and relying on Traditional Knowledge. For example, in exercising their powers, the land and water boards and the Review Board are directed to consider "any Traditional Knowledge and scientific information that is made available to it." ${ }^{39}$ Responsibility to consider all types of data also rests with the ministry responsible for monitoring the development in question. ${ }^{40}$ Nevertheless, there is little question that scientific accumulation, organization and interpretation of data rely on highly technical processes that privileges scientific processes.

The allocation of authority in the MVRMA also seems to fit within Usher's characterization of state management. The boards themselves are hierarchically organized and answer to the Department of Indian and Northern Affairs. They are also vertically compartmentalized, in so far as each is separated by both territorial jurisdiction and by the particular resources being managed (i.e. land and water, land use planning, wildlife, National parks etc.) Thus, each jurisdiction manages their resources separately.

\footnotetext{
${ }^{38}$ Usher, Peter J. 'Devolution of Power in the Northwest Territories,' in Native People and Renewable Resource Management, Symposium Proceedings of the Alberta Society of Professional Biologists (Edmonton: Alberta Society of Professional Biologists, 1986) 69.

${ }^{39}$ MVRMA, s 60 and s 115(1) (b).

${ }^{40}$ MVRMA, s 146. 'The responsible authority shall, subject to the regulations, analyze data collected by it, scientific data, Traditional Knowledge and other pertinent information for the purpose of monitoring the cumulative impact on the environment of concurrent and sequential uses of land and water and deposits of waste in the Mackenzie Valley.'
} 


\section{The Template: The Canadian Environmental Assessment Act}

In addition to similarities between the MVRMA and state management more generally, there are also striking similarities between the MVRMA and the Canadian Environmental Act [CEAA], which evidence it to be the MVRMA's template for environmental assessment. ${ }^{41}$ In the Mackenzie Valley, the legal framework for environmental assessment has changed dramatically over the last 20 years. Prior to the $M V R M A$, the $C E A A^{42}$ was the relevant legislation for environmental assessment. ${ }^{43}$ That the MVRMA is modeled on the CEAA is however, evidenced by the use of similar procedures, the statements of the Federal government regarding the MVRMA as well as the broader trend to harmonize environmental legislation between various jurisdictions in Canada. While there are differences between the CEAA and the MVRMA, a quick overview reveals the former to be the template for environmental assessment in the Mackenzie Valley.

For example, a comparison of the two statutes reveals the general purpose and procedures of the two statutes to be similar. Environmental assessment is a planning tool that requires early identification and evaluation of all potential environmental consequences of a proposed development and its alternatives. It is combined with a decision-making process that attempts to reconcile any approval of the proposed development with environmental protection and preservation. ${ }^{44}$ To this end, both the CEAA and MVRMA set up the regulatory scheme for environmental assessment and establish its process. They both aim to use their procedures to (1) predict the environmental effects of proposed projects before they are carried out; (2) propose measures to mitigate those effects; and (3) predict whether there will be significant adverse effects even after mitigation is implemented.

\footnotetext{
${ }^{41}$ For the argument that greater attention should be paid to how administrators or their associated interest groups impact the promulgation of legislation by bringing legislation into existence, commenting on proposed legislation, and consulting on technical language, see Harry W. Arthurs, Without the law: Administrative Justice and Legal Pluralism in Nineteenth-Century England (Toronto: University of Toronto Press, 1985) at 135.

42 Canadian Environmental Assessment Act, RSC. 1992, c 37.

${ }^{43}$ Prior to the MVRMA, almost all land and water use in the Northwest Territories was regulated by a territorial or federal body and in accordance with federal legislation. For example, oil and gas development in the Northwest Territories was administered by the Northern Oil and Gas Directorate of the Department of Indian Affairs and Northern Development ('DIAND') and the National Energy Board. Since 1985, this has taken place under the Canada Petroleum Resources Act, RSC 1985 c 36 and the Canada Oil and Gas Operations Act, RSC 1985, c 0-7, and their accompanying regulations. Licenses permitting the use of water and/or the deposit of waste were granted by the Northwest Territories Water Board under the Northwest Territories Waters Act, RSC 1992, c 39.

${ }^{44}$ For an overview of environmental assessment and other means of regulating mining in Canada see Joseph $\mathrm{F}$. Castrilli 'Environmental Regulation of the Mining Industry in Canada: An Update of Legal and Regulatory Requirements' (2000) 34 UBC L Rev 91.
} 
In terms of procedure, both statutes subject proposals to a graduated assessment scheme which routes the proposals to different levels of assessment depending upon the likelihood of significant adverse impact. Consequently, both statutes subject certain proposals to a preliminary screening (a succinct examination of a proposed development) and others are subjected to further environmental assessment. For example, both statutes require a preliminary screening where (1) the government is involved with permitting, licensing, or authorizing the proposal and (2) that proposal is identified in the regulations as included. If the screening determines that a proposal might have a significant adverse impact or might be a cause of public concern both statutes require further assessment. Similarly, both statutes exempt screenings where (1) there is no permit, licence or authorization, and (2) the impact on the environment is insignificant; or (3) it is an activity listed in an exempted/excluded regulatory list.

In addition to using the same graduated assessment scheme, both the MVRMA and the CEAA leave much of the procedural work to the governmental authority proposing or permitting the proposal. The relevant authority (called the responsible authority in the CEAA) determines the scope of the environmental assessment and is responsible for the early stages of the process, including the screening process for those projects likely to have routine or low impacts. Under the MVRMA, the various resource boards carry out the screening process and refer certain projects for environmental assessment.

Just as the general purposes and procedures of the two statutes are similar, so too are the regulatory lists which determine which proposals are automatically included or excluded. This explains why, in its Regulatory Impact Analysis, the Department of Indian and Northern Affairs stated that the Preliminary Screening Requirement Regulations and the Exemption List Regulation of the MVRMA have been "modeled on and work in a similar fashion to the Canadian Environmental Assessment Act Law List Regulations and Exclusion List Regulations." ${ }^{\prime 5}$ It is noteworthy that in rejecting the proposal that the MVRMA should use exactly the same inclusion/exclusion regulations as the CEAA, the department argued that the "proposed regulations are adapted to the circumstances in the Mackenzie Valley. They carry out Canada's obligation respecting the implementation of the Gwich'in and Sahtu Land Claim Settlement Agreements." $^{46}$

Nevertheless, the Department of Indian and Northern Affairs has asserted that "[g]iven their similarity to CEAA, they offer some familiarity and continuity throughout the federal system." In weighing the benefits and costs of a different system in the Mackenzie Valley, the Department of Indian and Northern Affairs argued "A system so similar to the CEAA regulations does not require much adaptation from stakeholders, proponents and federal regulatory authorities or

\footnotetext{
${ }^{45}$ Preliminary Screening Requirement Regulations, Regulatory Impact Analysis Statement, Canada Gazette Vol. 132 No. 30-July 25, 1998. For a discussion of regulatory impact analysis statements see P. Salembier, Regulatory Law and Practice in Canada (Markham, Ontario: LexisNexis Butterworths, 2004) 83-94.

${ }^{46}$ Regulatory Impact Analysis Statement, C Gaz. 1998.I.1798 (Mackenzie Valley Resource Management Act, Preliminary Screening Requirement Regulations.
} 
increase operating costs...the level of EAR would not significantly increase in the Mackenzie Valley. It is therefore not anticipated that these regulations would limit competitiveness or unduly affect small and medium business more than the current CEAA regulations." ${ }^{47}$ Whether harmonization has resulted from this shared list is questionable. The Review Board has already interpreted differences between the lists in light of the treaties. ${ }^{48}$ However, these governmental statements reveal an intention to create a system of resource management in the North that implements treaty obligations but generally maintains continuity with systems already in place. ${ }^{49}$

Moreover, this approach aligns with long-standing goals of the federal government to harmonize environmental standards across the country. In Canada, the harmonization of federal and provincial standards with respect to the environment has been a priority for Federal Environment Ministers for the last 20 years. This tendency to harmonization has resulted in initiatives such as the Canada Wide Accord on Environmental Harmonization, a framework agreement between the federal and provincial governments to coordinate environmental programs and policies. ${ }^{50}$ Aimed at achieving the benefits of harmonization, its objectives are to "enhance environmental protection, promote sustainable development and achieve greater effectiveness, efficiency, accountability, predictability and clarity of environmental management for issues of Canada-wide interest." ${ }^{51}$

${ }^{47}$ Ibid.

${ }^{48}$ Mackenzie Valley Environmental Impact Review Board. Reference Bulletin: Preliminary Screening Conducted by Governments and First Nations as Developers - Section 124(2) of the Mackenzie Valley Resource Management Act (Northwest Territories: Mackenzie Valley Environmental Impact Review Board, January 2005) available at www.reviewboard.ca.

${ }^{49}$ For further evidence that the MVRMA is a product of federal conceptualizations of resource management see Julia Christensen and Miriam Grant, 'How Political Change Paved the Way for Indigenous Knowledge: The Mackenzie Valley Resource Management Act' (2007) 60:) Arctic 115 at 120.

${ }^{50}$ In November 1993, the Canadian Council of Ministers of the Environment agreed to make harmonization a top priority. They directed their officials to work on a new 'Environmental Management Framework for Canada'. Following long consultations, negotiations and draft attempts, the 12 ministers of the Environment, representing the provincial, federal, and territorial governments signed the Canada-Wide Accord on Environmental Harmonization, January 29, 1998.

${ }^{51}$ Ibid. For the benefits of harmonization, see Steven A. Kennett, ed, 'Inter-jurisdictional Harmonization of Environmental Assessment in Canada' in Law and Process in Environmental Management: Essays from the Sixth CIRL Conference on Natural Resources Law (Calgary: Canadian Institute of Resource Law, 1993). 


\section{The Comparator: Indigenous Traditions}

The discussion so far has situated the MVRMA in state management systems and specifically, the CEAA. ${ }^{52}$ Do Indigenous peoples in the Mackenzie Valley have their own traditions related to resource management, which can be differentiated from those of the MVRMA? They clearly do. In fact, one of the most prominent themes in the scholarship on co-management and Traditional Knowledge is the different conceptual frameworks, methodologies and underlying values of the two approaches to resource use. ${ }^{53}$

The growing contribution of scholars writing from an Indigenous perspective provides important insight into the distinct characteristics of Indigenous knowledge and its impact on the construction of legal authority vis a vis resource use. ${ }^{54}$ That research has characterized the nature of those laws as originating in values and principles that are distinguishable from rational-legal approaches to resource use. ${ }^{55}$ As a result, it is becoming increasingly clear that Indigenous peoples have particular theoretical understandings of resource law and ways of communicating law that can be differentiated from other legal traditions. ${ }^{56}$ For instance, Battiste and Henderson argue that Indigenous legal traditions operate at various levels to govern Indigenous communities in ways that reflect particular aspects of Indigenous knowledge. ${ }^{57}$ Those particular aspects share certain beliefs such as the following:

52 'The institutions of liberal democracy, with all of their merits and disadvantages, were 'planted' in the North gradually: undemocratic colonial administration was the first transplant, and fully electoral government evolved only in the last two decades' Abele, F. 'Traditional Knowledge in Practice' (1997) 50:4 Arctic iii-iv.

${ }^{53}$ Researchers compare Indigenous values, practices and beliefs to the conceptual framework of the scientific resource management system. Paul Nadasdy, Hunters and Bureaucrats: Power, Knowledge and Indigenous State Relations in the Southwest Yukon (UBC Press: Vancouver, 2003) [Nadasdy, 'Hunters'], White, supra note 11. For an important caveat on differentiating Western from Indigenous legal traditions when characteristics can be shared and changeable see Berman, supra note 34.

${ }^{54}$ For example, see Mary E. Turpel, 'Indigenous Peoples and the Canadian Charter: Interpretive Monopolies, Cultural Differences' (1989-90) 6 Canadian Human Rights Yearbook 3, John Borrows, Recovering Canada: The Resurgence of Indigenous Law (Toronto: University of Toronto Press, 2002), John Borrows, 'Indigenous Legal Traditions' (Ottawa: Law Commission of Canada, 2006), Val Napoleon \& Richard B. Overstall. Indigenous Laws: Some Issues Considerations and Experiences (Winnipeg, Manitoba: Centre for Indigenous Environmental Resources, 2007).

55 The description of Indigenous laws related to resource use has long been the object of anthropological research. Legal pluralists have argued that Indigenous people, located within territorial boundaries of the modern nationstate, exist within a matrix of multiple legal orders that can be characterized as state based and non-state based. For examples of the earliest approaches to Indigenous laws, see Bronislaw Malinowski, Crime and Custom in Savage Society (London: Routledge \& K. Paul, 1926).

${ }^{56}$ For the import of this theoretical development see Gordon Christie, 'Indigenous Legal Theory: Some Initial Considerations' in Benjamin J. Richardson, Shin Imai and Kent McNeil, eds, Indigenous Peoples and the Law: Comparative and Critical Perspectives (Oregon: Hart Publishing, 2009) 195.

57 Marie Battiste \& James (S.)Y. Henderson, Protecting Indigenous Knowledge and Heritage: A Global Challenge (Saskatoon: Purich Publishing, 2000), P. Monture-Angus, Journeying Forward: Dreaming Indigenous Independence (Halifax: Fernwood Publishing, 1999) 55, Val Napoleon, Ayook: Gitksan Legal Order, Law, and Legal Theory (PhD thesis, University of Victoria, 2009). 
1. knowledge of and belief in unseen powers in the ecosystem,

2. knowledge that all things in the ecosystem are dependent on each other,

3. knowledge that reality is structured according to the linguistic concepts by which Indigenous peoples describe it

4. knowledge that personal relationships reinforce the bond between person, communities and ecosystems

5. Knowledge that sacred traditions and persons who know these traditions are responsible for teaching morals and ethics to practitioners who are then given responsibility for this specialized knowledge and its dissemination

6. Knowledge that an extended kinship passes on teaching and social practices from generation to generation. $^{58}$

Traditional Knowledge is often raised as providing entirely different conceptual frameworks, methodologies and underlying values than those provided by rational-legal approaches. There is a wide debate on what is meant by Traditional Knowledge and its use in a bureaucratic context. One of the most cited descriptions of Traditional Knowledge offered is that it is "a cumulative body of knowledge, practice and belief, evolving by adaptive processes and handed down through generations by cultural transmission, about the relationship of living beings (including humans) with one another and with their environment". ${ }^{59}$ Battiste and Henderson refer to Traditional Knowledge as Indigenous ways of knowing about the world. ${ }^{60}$ It describes the foundations of Indigenous societies. It is not confined to a collection of objects or stories and ceremonies that record past practices. Instead, it describes the heritage of Indigenous peoples as complete knowledge systems with their own concepts of epistemology, philosophy, and scientific and logical validity. ${ }^{61}$ Its relevance comes from its changing use and is not limited to beliefs and customs frozen at a particular point in the distant past. ${ }^{62}$

A specific example of Traditional Knowledge related to resource use by the Dogrib (Tlicho) people in the Mackenzie Valley can be found in the Dene Traditional Justice Project. ${ }^{63}$ This

\footnotetext{
${ }^{58}$ For an elaboration on this structure see Battiste \& Henderson, Ibid at 42 . Also see James (S.Y.) Henderson, 'PostColonial Indigenous Legal Consciousness (2002) 1 Indigenous Law Journal 1, and James (S.Y.) Henderson, Indigenous Jurisprudence and Indigenous Right: Defining the Just Society (Saskatoon: Native Law Centre of Canada, 2006).

${ }^{59}$ Fikret Berkes, Sacred Ecology: Traditional Ecological Knowledge and Resource Management (Philadelphia, PA : Taylor \& Francis,1999) at 8.

${ }^{60}$ Battiste, \& Henderson, supra note 56 at 134-5.

${ }^{61}$ Ibid.

${ }^{62}$ Nadasdy, Hunters, supra note 52 at 120.

63 J. Ryan, Doing Things the Right Way: Dene Traditional Justice in Lac La Martre, N.W.T. (Calgary: University of Calgary Press, 1995). Other sources of Dene legal traditions based on Traditional Knowledge can be found in
} 
project examined a number of areas in which a system of rules had been established. Rules for stewardship related to maintaining the balance between land, animals, plants, spirits, and people and were based on the principle of survival and reciprocal relationships among the human, animal, and natural worlds. ${ }^{64}$ What traditions like these mean for large-scale industrial projects remains unexplained in the literature. However, from even the briefest comparison to the MVRMA, it is apparent that it does not purport to represent Indigenous traditions on resource use in its own language.

This insight is well analyzed in an article by the political scientist, Graham White, in which he contrasts the MVRMA against the characteristics of traditional Indigenous governance. ${ }^{65} \mathrm{He}$ provides an overview of some of the essential differences between the two styles of governance. For example, instead of the command and control structure of hierarchical bureaucracy, he characterizes traditional Indigenous societies as egalitarian and nonhierarchical. ${ }^{66}$ Rather than relying on formal power, which ends when an individual leaves office, authority is exercised by giving advice or sharing knowledge, which remains with the individual for life. Instead of relying on extensive impersonal rules, Traditional Knowledge emphasizes simplicity and flexibility. Instead of the emphasis on documents and written rules, Indigenous peoples rely on oral communication. Instead of compartmentalized knowledge about particular species or resources, Indigenous knowledge is more holistic. Instead of a bureaucrat's merit being determined by educational credentials, Indigenous peoples value practical experience on the land. Instead of using an adversarial approach to disagreement, Northern Indigenous societies are non-confrontational with decisions reached by consensus after prolonged seemingly deferential discussion. ${ }^{67}$ In short, the MVRMA reflects none of the characteristics of Indigenous management. It instead reflects the characteristics of state management typical of other resource management initiatives of the federal and provincial governments of Canada. Consequently, despite its participatory objectives, the MVRMA is effectively a transplant of the CEAA and reflects its central organizing principles related to state management.

George Blondin, Yamoria the Lawmaker: Stories of the Dene (Edmonton: NewWest, 1997); Vuntut Gwitchin First Nation \& Shirleen Smith, People of

Van Tat Gwich'in (Edmonton: University of Alberta Press, 2009).

${ }^{64}$ Joan Ryan, Doing Things the Right Way: Dene Traditional Justice in Lac La Martre, N.W.T. (Calgary: University of Calgary Press, 1995) 34-36.

${ }^{65}$ White, supra note 11 . White seems to reference characteristics generally associated with Indigenous practices rather than any specific Dene tradition.

${ }^{66}$ For a more complex understanding of Indigenous societies, see Val Napoleon, in Benjamin J. Richardson, Shin Imai and Kent McNeil, eds, Indigenous Peoples and the Law: Comparative and Critical Perspectives (Portland, OR: Hart Publishing, 2009).

${ }^{67}$ White, supra note 11 . White answers a question posed by Frances Abele: 'whether the historical values and practices of Dene or Inuit society, as they have survived the massive changes of the last century, are at all compatible with modern governing procedures, mass societies and public bureaucracies.' Frances Abele, 'Traditional knowledge in Practice' (1997) 50:4 Arctic iii-iv. 
Critics of the transnational use of transplants in law reform projects similarly suggest that irrespective of participatory goals, the transplantation of law and institutions can prevent local perspectives from impacting law's development. ${ }^{68}$ This phenomenon can be ascribed to an assumption that the meaning of a transplanted rule will be harmonized with the donor's meaning, thereby preventing the alteration or adaptation of the law to reflect the local context. Harmonization assumes that the reception of a donor's laws includes reception of both the written and unwritten rules upon which the donor's law rests. Therefore, instead of law reflecting the values and perspectives of those impacted, it becomes a technical tool by which to harmonize rules and meaning across geographical and cultural divides.

It might be argued that the assumption that transplanted laws will reflect the donor's meaning may seem obvious to those involved in law reform. The goal of law and development doctrine, stated simply, is to use legal reforms to support the improvement of social and economic development in various countries. ${ }^{69}$ Transplants have been used, arguably throughout history but especially in conscious law reform, to harmonize laws to achieve this objective. ${ }^{70}$ Domestic legislatures draft laws which copy statutes from other countries or remove laws that would otherwise inhibit free market systems. Those legislative initiatives are notable for their assumption that the transplantation of legal rules should result in the transplantation of their meaning and effect. Instead of reflecting the values of the host, the law is intended to reflect the values of the donor.

There are, however, significant concerns with the impact of transplantation and harmonization on the host's culture. Using a comparative approach, transplantation has been criticized as a technical use of law that misconstrues transplants as benign law reform. ${ }^{71}$ Instead, the critical literature recasts transplants as a tool which allows predominantly Western European and

68 Nehal Bhuta, 'Against State-Building' (2008) 15 Constellations: An International Journal of Critical and Democratic Theory 517.

${ }^{69}$ David. Trubek and Alvaros Santos, 'Introduction: The Third Moment in Law and Development Theory and the Emergence of a New Critical Practice' in David Trubek and Alvaros Santos, eds, The New Law and Economic Development: A Critical Appraisal (Cambridge: Cambridge University Press, 2006) 1 at 4-6.

${ }^{70}$ For a discussion in relation to waves of law and development see Duncan Kennedy, 'Three Globalizations of Legal Thought: 1850-2000' in David Trubek and Alvaros Santos, eds, The New Law and Economic Development: A Critical Appraisal (Cambridge: Cambridge University Press, 2006) 19.

${ }^{71}$ Katharina Pistor, 'The Standardization of Law and its Effect on Developing Nations' (2002) 50:1 The American Journal of Comparative Law 97. Pistor argues that harmonization may undermine the development of effective legal system because it ignores two characteristics of legal systems: 1 interdependence and 2) law as a cognitive institution. For an example of a technical approach, see Alan Watson, Legal Transplants (Edinburgh: Scottish Academic Press Ltd, 1974) who asserts that law is like a technical invention, such as the wheel. Compare this against Otto Kahn-Freund, 'On the Use and Misuse of Comparative Law' (1974) 37 Modern Law Review 1. For discussion see William Ewald, 'Comparative Jurisprudence (II): The Logic of Legal Transplants' (1995) 43 American Journal of Comparative Law 489. 
North American concepts, couched in particular laws, to determine legal, social and political relationships in other countries. ${ }^{72}$ It is viewed as a series of rational suppositions and postulates that are applied as if political and social spaces are homogenous or sufficiently law-free to receive new law. Addressing the impact of this approach on Indigenous knowledge, Henderson and Battiste argue that claims to Eurocentric thought, such as these, connect colonialist methodology to present day state-building. ${ }^{73}$ While colonialism may not be the intent, a transplant analysis reveals that the concept that law can be diffused throughout the world is itself premised on particular understandings of law as a technical tool. Seen in this light, harmonization and the idea of using a common core of legal standards reflects a concept of law which analytically separates law from the social, political and economic context in which it is expected to operate. ${ }^{74}$

Identifying the MVRMA as a transplant clarifies that co-management funnels the relevance of Indigenous perspectives grounded in Indigenous traditions through the participatory mechanisms of the MVRMA. Rather than using Indigenous traditions, using Indigenous language or derived from use in an Indigenous social context, the MVRMA derives from a bureaucratic perspective, uses the English language, and was developed in a non-Indigenous context. Consequently, it does not generally reflect the principles upon which Northern Indigenous peoples have used the land and wildlife in the past. The structure and processes upon which the legislation rests reflects the principles of resource management used by the Federal government of Canada.

A discussion of transplantation is not raised here to argue that formal power should be restructured. Given the acquiescence of Indigenous peoples in the Mackenzie Valley to the MVRMA through treaties, transplantation does not necessarily mean injustice. The comanagement scheme in the MVRMA resulted from extensive treaty negotiations over a 20-year period. Thus, Indigenous governments of the Mackenzie Valley acquiesced to the MVRMA. While adopting Federal government processes for resource management may not have been the first choice of the Indigenous signatories, characterizing this consent as oppressive likely overstates it. ${ }^{75}$ Instead, Indigenous governments knowingly agreed to participate in resource management largely premised on state management processes and principles.

\footnotetext{
72 Maxwell O. Chibundu 'Law in Development: On Tapping, Gourding and Serving Palm Wine' (1997) 29 Case Western Reserve Journal of International Law 167 at 242.

${ }^{73}$ Battiste \& Henderson, supra note 56 at 21.

${ }^{74}$ David Trubek and Alvaros Santos, 'Introduction: The Third moment in Law and Development Theory and the Emergence of a New Critical Practice' in David Trubek and Alvaros Santos, eds, The New Law and Economic Development: A Critical Appraisal (Cambridge: Cambridge University Press, 2006) 1. For examples of this approach and the continuity of colonialist heritage of transplants see Upendra Baxi, 'The Colonialist Heritage' in Pierre Legrand and Munday, eds, Comparative Legal Studies: Traditions and Transitions (Cambridge: Cambridge University Press, 2003) at 53 who argues that colonial inheritances makes it impossible to disengage the colonial form the post-colonial and neo-colonial.

${ }^{75}$ For example of an approach which sees a continuing colonialist legacy see Upendra Baxi, 'The Colonialist Heritage' in Legrand and Munday, eds, Comparative Legal Studies: Traditions and Transitions (Cambridge: Cambridge University Press, 2003).
} 
Instead, a transplantation analysis forces the recognition that the laws that structure decisionmaking do not expressly reflect Indigenous traditions on resource management. The MVRMA may not preclude Indigenous traditions. However, it reproduces processes that reflect the same rational legal principles of similar agencies across Canada. ${ }^{76}$ Identifying the MVRMA as a transplant reveals that co-management is itself a legal construct rooted in particular legal discourse that organizes how Indigenous perspectives can be identified and managed. Of course, this is true of any legal institution. However, where harmonization of meaning prevents the social context, introduced through local participation, from manifesting in the law, it arguably limits the impact of participation. ${ }^{77}$

\section{B. JUDICIAL INITIATIVES FOR HARMONIZATION}

The impact of harmonizing legislation is illustrated by the spurt of cases that have reviewed decisions under the MVRMA over the last 10 years. There are only a handful of cases to have interpreted the MVRMA in light of other statutory schemes. ${ }^{78}$ These cases, however, illustrate how an assumption of harmonization has found some traction in the interpretation of authority pursuant to the MVRMA. The decisions discussed here generally deal with statutory interpretation and the standard of review to be applied. Through these cases, however, the courts have explicitly and implicitly grappled with the relationship between participation and interpretation of the MVRMA.

The following discussion highlights the different outcomes that result from a view of two legislative schemes, the MVRMA and its predecessor, the CEAA, as harmonious or distinct. Assumptions about the drafting and intention of the MVRMA motivate its understanding as similar to or different from the CEAA. Where the MVRMA is understood to incorporate much of the same structure of the CEAA, it is interpreted as carrying forward much of the same meaning. In these cases, little thought has been given to how the boards' interpretations of the

\footnotetext{
${ }^{76}$ The extensive critical scholarship on co-management confirms this expectation. It affirms that the rational-legal traditions of state management are more determinative of resource management than are Indigenous traditions, supra note 11 .

77 Through their discussions about social context and the power of legal reform, scholars in this field address problems with participatory and non-participatory measures for lawmaking in multiple regulative contexts. See for example Kerry Rittich, 'The Future of Law and Development: Second-Generation Reforms and the Incorporation of the Social' in David Trubek \& Alvaros Santos, eds, The New Law and Economic Development: A Critical Appraisal (Cambridge: Cambridge University Press, 2006) 203.

${ }^{78}$ K'a'Gee Tu First Nation v. Canada (Attorney General) [2007] FC 764, North American Tungsten Corp. Ltd. v. Mackenzie Valley Land and Water Board [2002] NWTJ 89 Reversed in North American Tungsten Corp. Ltd. v. Mackenzie Valley Land and Water Board [2003] NWTJ 28, Canadian Zinc Corp. v. Mackenzie Valley Land and Water Board [2005] NWTJ No. 41, De Beers Canada Inc. v. Mackenzie Valley Environmental Impact Review Board [2007] NWTJ No. 26, and BHP Billiton Diamonds Inc. v. Wek'èezhii Land and Water Board [2010] NWTSC 23.
} 
MVRMA represent particular values that are not represented in the $C E A A .^{79}$ In contrast, where the goals of the MVRMA are distinguished from the CEAA, interpretive differences are allowed. The following three summaries introduce the central interpretive issue upon which the decisions turned.

\section{North American Tungsten Corp. Ltd. v. Mackenzie Valley Land and Water Board}

In North American Tungsten Corp. Ltd. v. Mackenzie Valley Land and Water Board, ${ }^{80}$ the court explicitly considered the interpretive similarities between the MVRMA and the CEAA. In this case, North American Tungsten applied for a water license renewal for a mine and milling operation. It first received the license in 1975 and renewed it at various intervals. It argued that because it sought a renewal it was statutorily exempted from environmental assessment. The company argued that it fell under a clause that grandfathered its exemption. The Mackenzie Valley Land and Water Board decided the exemption did not apply and the license application required an environmental assessment.

The case turned on the interpretation of s.157.1. Generally, the MVRMA requires that proposals comply with an environmental assessment process consisting of a preliminary screening by the regulatory authority and, if applicable, environmental assessment by the Review Board. Section 157.1 exempts a 'license, permit or other authorization related to an undertaking that is the subject of a license or permit issued before June 22, 1984.' The case and its subsequent appeal turned on whether s. 157.1 grandfathers a license issued prior to June 22, 1984 or an undertaking licensed prior to June 22, 1984.

The Mackenzie Valley Land and Water Board focused on whether Tungsten's current water license was a continuation of a license issued before June 22, 1984. The Board concluded that the application was, in effect, an application for a new license and therefore not exempted. Tungsten applied to the Northwest Territories Supreme Court for judicial review of the Board's decision. On judicial review, Tungsten and the Attorney General argued that s. 157.1, read in its statutory context and in light of s. 74(4) of the CEAA, exempted Tungsten's application. They argued that despite different language, s.157.1 was meant to mirror the meaning of s. 74(4) of the CEAA which grandfathers undertakings or projects that were commenced or underway before June 22, 1984. ${ }^{81}$ Thus, the Attorney General argued the exemption in s. 157.1 applied to the applicant and the Board was incorrect in holding that it did not.

\footnotetext{
79 Joseph Castrilli remarks that while the MVRMA represents a geographically sensitive approach to federal environmental assessment, it incorporates much of the same structure as the CEAA and hence can be interpreted as carrying forward much of the same meaning. Castrilli, supra note 43.

${ }^{80}$ North American Tungsten Corp. Ltd. v. Mackenzie Valley Land and Water Board [2002] NWTSC 76 Reversed in North American Tungsten Corp. Ltd. v. Mackenzie Valley Land and Water Board [2003] NWTCA 5 [Tungsten].

${ }^{81}$ Section 157(1) of the MVRMA states 'Part 5 does not apply in respect of any licence, permit or other authorization related to an undertaking that is the subject of a licence or permit issued before June 22, 1984'. Section 74(4) of the CEAA states, 'Where the construction or operation of a physical work or the carrying out of a physical activity was initiated before June 22, 1984, this Act shall not apply in respect of the issuance or renewal of a licence, permit, approval or other action under a prescribed provision in respect of the project'
} 
In the Northwest Territories Supreme Court, Justice Schuler disagreed with the interpretation offered by Tungsten and the Attorney General. Most importantly, he disagreed with the premise that the MVRMA should be interpreted in accordance with the CEAA. ${ }^{82}$ Using a purposive approach to statutory interpretation, ${ }^{83}$ the court interpreted s.157.1 in the context of the entire statutory scheme, its object and the intention of Parliament. To Schuler, J. the object of the MVRMA, as revealed in the preamble and purpose section, was to create a differentiated scheme for land and water use management in the Mackenzie Valley. To this end he states: 'Since the MVRMA replaces the CEAA and contains different language from the latter, it is clear that the intent was not simply to re-create the CEAA regime under the auspices of new legislation. ${ }^{84}$ Based on the principle that the MVRMA and CEAA are to be interpreted distinctly, he argued that the change in wording from s. 74(4) of the CEAA to s. 157.1 of the MVRMA is significant. The change in wording 'indicates a shift away from grandfathering 'old', that is, preJune 22, 1984 undertakings, to grandfathering only those undertakings which still hold a license issued before June $22,1984 .{ }^{85}$ He recognized that the consequence of this interpretation was that undertakings that would be grandfathered under the CEAA would not be grandfathered under the MVRMA. However, he ascribed this intention to the legislators. ${ }^{86}$

The Northwest Territories Court of Appeal did not share Schuler J.'s interpretation. It overturned Schuler J.'s findings and held for Tungsten. Interestingly, the court also used a purposive approach to interpretation and read the section in the context of the statute as a whole. ${ }^{87}$ However, it found that the object and intent of the statute supported the position that s.157.1 was meant to parallel the CEAA and grandfather old undertakings from review. The court in Tungsten did note that the stated purpose of the statue was to establish boards to enable residents of the Mackenzie Valley to participate in resource management. However, it argued that another purpose of the MVRMA is to grandfather existing developments in order to balance competing interests. ${ }^{88}$ Against this construction of the object of the Act, the Court of Appeal turned its attention to the specific wording of s. 157.1 and read it as complementary to the CEAA. ${ }^{89}$ Turning its attention to the wording of s.157.1, the court found that similar wording as to the date for which licenses are grandfathered reflected Parliament's intention to have the

\footnotetext{
${ }^{82}$ The court found this assumption inconsistent with the intent to vest regulatory power in Indigenous peoples, as set out in the preamble to the MVRMA. North American Tungsten Corp. Ltd. v. Mackenzie Valley Land and Water Board [2002] NWTSC 76 para 33.

${ }^{83}$ Bell Express Limited Partnership v. Rex [2002] SCJ No. 43, at para 26 and 27.

${ }^{84}$ North American Tungsten Corp. Ltd. v. Mackenzie Valley Land and Water Board [2002] NWTSC 76 at para18.

${ }^{85}$ Ibid at para 31.

${ }^{86}$ Ibid.

${ }^{87}$ Tungsten, at para 21.

${ }^{88}$ Ibid at para 24.

${ }^{89}$ Ibid at para 29.
} 
provisions treated similarly. ${ }^{90}$ However, different wording was meant to reflect an attempt to address some interpretive difficulties that had arisen around the word 'initiated' in the CEAA, an issue unrelated to this case. ${ }^{91}$ In short, the court denied that the difference in wording between the two statutes was meant to reflect a parliamentary intention to broaden the scope of projects subject to assessment. ${ }^{92}$

In its concluding remarks, the court focused on the policy implications of the lower court's holding. The court reasoned that if the holding is correct then, as of June 22, 2009, no undertakings requiring water licenses would be grandfathered since the longest water license possible under the Waters Act was 25 years. Absent a clear intention of Parliament, the court rejected an interpretation of s. 157.1 which would require all water license renewals to be subject to a full-scale environmental review under Part 5 by that date. To the court, such an approach would be inconsistent with the concept of grandfathering and would strip s. 157.1 of certainty, of fairness and, ultimately, of effect because grandfathering would be understood as a passing state under the MVRMA.

\section{Canadian Zinc Corp. v. Mackenzie Valley Land and Water Board}

A subsequent case that considered the same issue in regards to a license to use a winter road came before Schuler J. in Canadian Zinc Corp. v. Mackenzie Valley Land and Water Board. ${ }^{93}$ Canadian Zinc Corp. (CZC) bought mine assets from Cadillac, a corporation that held an expired license to use the winter road and went bankrupt. On applying for a license, CZC submitted to the Board that it should have the benefit of the s. 157.1 exemption because Cadillac had a permit issued for the road before June 22, 1984. The Board concluded that CZC was involved in a different undertaking than that which Cadillac was involved in before June 22, 1984 and that the permit sought by CZC 'is not in respect of the undertaking originally permitted to Cadillac.' Schuler J. again had to decide whether an exempted license under s.157.1 must have some relationship in terms of subject matter, substance, and direct linkage to the license in respect of which a renewal application has been filed.

First, Schuler J. considered the meaning of 'undertaking' under s.157.1. CZC argued that the 'undertaking' in question is the winter access road. In contrast, the interveners argued that the 'undertaking' is the larger enterprise engaged in by CZC. Both relied in part on Tungsten to support their positions. For his part, Schuler J. relied on Tungsten's precedent that the MVRMA

\footnotetext{
${ }^{90}$ Ibid.

${ }^{91}$ According to the court, prior uncertainty over what is meant by the word 'initiated' under the CEAA provoked Parliament to alter s. 157.1 to refer to an event which could be easily and conclusively established for a given project without litigation - that is, the actual date on which a licence or permit had been issued. Ibid.

${ }^{92}$ Ibid at para 29. On the contrary, the court muses that the MVRMA exemption may be broader than that under CEAA since (1) the MVRMA exemption applies as long as the relevant licence or permit was issued prior to June 22, 1984 regardless of whether physical work on the project had been initiated by that date.

${ }^{93}$ Canadian Zinc Corp. v. Mackenzie Valley Land and Water Board [2005] NWTSC 48 [Canadian Zinc].
} 
and the CEAA are meant to complement each other. Consequently, he interpreted 'undertaking' to align with the meaning of the language of the CEAA, even though s. 74(4) of the CEAA does not use the word 'undertaking'. ${ }^{94}$ He explained consistency to be his modus operandi, stating, 'In my view, to be consistent with the CEAA and the context and purpose of the legislation as described in Tungsten, the definition of undertaking must parallel the wording used in the CEAA and not focus solely on the physical 'thing', that is, the winter access road. ${ }^{95}$ Based on this interpretative consistency, the court overturned the scope of the license with which the board was operating and inserted its own understanding. ${ }^{96}$ By doing so, he altered the scope of oversight the board had of the mining operation and confined it to the operation of the road. This divorced the use of the road from the larger mining operation carried on by CZC.

In turning his mind to whether there needed to be a direct linkage between the permit that expired prior to June 22, 1984 and the current one being sought by CZC, Shuler J. again turned to the CEAA for interpretive guidance. He reasoned that, 'if a purpose of the CEAA and the $M V R M A$ is to exempt projects from environmental assessment when significant resources have already been expended towards them, it would seem to follow that when such a project has been taken over by a new owner, one which has also expended significant resources to acquire the project, the exemption follows the project. In other words, it is the project or undertaking that is exempt from s. 157.1, not the owner or the permit holder. ${ }^{\prime 97}$

Based on this understanding, the court concluded that the mere desire to operate the winter access road was a sufficient connection in terms of subject matter and substance between CZC's proposed undertaking and Cadillac's undertaking. He denied the need to establish the continuity of ownership to benefit from the exemption, even though the license had lapsed. The mere fact that it had existed prior to June 22, 1984 allowed it to vest in the new owner of the mine.

\footnotetext{
${ }^{94}$ The CEAA uses the language 'physical work or the carrying out of a physical activity' and 'project'. Project' is defined as 'in relation to a physical work, any proposed construction, operation, modification, decommissioning, abandonment or other undertaking in relation to that physical work'. CEAA, s. 2(1).

${ }^{95}$ Canadian Zinc at para 4.

${ }^{96}$ Canadian Zinc at para 54 where the court stated: 'If the MVRMA and CEAA are meant to be complementary pieces of legislation, one would not expect the legislators to change the focus from a physical work or activity under CEAA to the larger business or enterprise within which that physical work or activity takes place under MVRMA in determining whether a project is grandfathered and exempt from environmental assessment.'

${ }^{97}$ Ibid.
} 


\section{De Beers Canada Inc. v. Mackenzie Valley Environmental Impact Review Board}

The third and most recent case to contemplate the relationship between the MVRMA and the CEAA is De Beers Canada Inc. v. Mackenzie Valley Environmental Impact Review Board. ${ }^{98}$ The reasoning in this case departs significantly from the earlier decisions and importantly differentiates the MVRMA from the CEAA. In this case, De Beers sought judicial review of an order of the Review Board for an environmental impact review, where no environmental assessment had been completed - as required under the CEAA.

The case turned on three issues. The first was whether the Review Board has the authority to order an environmental impact assessment without first completing an environmental assessment. The second issue was whether the Review Board committed other errors that exceed its jurisdiction (such as sub-delegation, prejudging the issue, and irrelevant factors). The last issue was whether the Review Board erred in finding that the project was likely to be a cause of significant public concern. ${ }^{99}$

The first issue turned on the meaning of the word 'consideration' in the MVRMA. Section $117(2)$ requires that every environmental assessment and environmental impact review of a proposal for a development shall include a 'consideration' of a number of factors. De Beers argued that the word 'consideration' creates a requirement that the Review Board analyze and make findings about all the subjects enumerated in that subsection prior to ordering an impact review. Since the Review Board had not made a finding about each subject, it had not completed the environmental assessment and had no jurisdiction to order the impact review. In support of its proposition, De Beers relied on the meaning of the word 'consideration' as used in s. 16 of the CEAA and interpreted in another case. ${ }^{100}$

Interestingly, the Northwest Territories Supreme Court found the analogy unconvincing. Justice Charbonneau recognized the use of similar language in different statutes as helpful to interpretation but rejected its application here. Instead, he declared 'I am not persuaded, however, that the meaning given to the term 'consideration' in the context of the CEAA is particularly helpful in resolving the statutory interpretation issue in this case. ${ }^{101}$ Justice Charbonneau cited various reasons for this interpretive turn: that the term 'consideration' is not a particularly technical word, that use of the word 'consideration' instead of 'determination' is significant and that the ordinary meaning of the word does not imply exhaustive review. In addition, the court distinguished the MVRMA from the CEAA. Charbonneau J. noted that while there are some similarities between the two statutes, there

\footnotetext{
${ }^{98}$ De Beers Canada Inc. v. Mackenzie Valley Environmental Impact Review Board [2007] NWTSC 26 [De Beers].

${ }^{99}$ The court characterized the first two issues as matters of statutory interpretation, for which no deference was owed to the Review Board. It characterized the last issue, whether there was public concern, as an issue of fact, for which considerable deference was warranted. Ibid.

${ }^{100}$ Alberta Wilderness Assn. v. Cardinal River Coals Ltd. [1999] 3 FC 425.

${ }^{101}$ De Beers at para 37
} 
are also some differences. More specifically, he noted that the 'Act is unique in the context of its adoption, the importance of the role given to the Review Board, and the importance it places on public concern. ${ }^{102}$

What is interesting about this case is the way in which the court grounded its support for the Review Board's actions in its distinctive goals. For example, De Beers claimed that the board erred in finding that the project was likely to be a cause of significant public concern. Addressing this claim, the court held that the Review Board is entitled to considerable deference on its findings. The court characterized the board's role as 'balancing of the various interests and factors' as 'the very heart of its role as the main instrument in the Mackenzie Valley for the environmental assessment and environmental impact review of proposals for developments. ${ }^{103}$ Moreover, the court supported the Review Board's reliance on community workshops and hearings to obtain evidence of public concern about protection of wildlife, water quality and quantity, contaminants, the impact of development on communities, and the fact that two culturally and spiritually significant sites had the potential of being affected by the Project. The court did not analyze the quality of those concerns nor did it require the board to analyze the quality of those concerns. Instead, the court determined that the MVRMA intended to empower the board to act on public concern - not whether the public concern is justified according to another evaluative system.

\section{DISCUSSION - CONCERNS}

To date, these are the only three cases to directly contemplate the relationship between the MVRMA and the CEAA. Both Tungsten and Canadian Zinc stand for the ratio that Parliament intended the meaning of s.157.1 in the MVRMA to be harmonized with that of the CEAA. The courts did not use the term 'harmonization' in their judgments, preferring the term 'complementary'. However, the critical question, which guided the interpretation and application of the MVRMA in these cases, was whether Parliament intended the MVRMA to be interpreted in accordance with the CEAA. Put into the language of transplantation, this issue becomes a question of harmonization. In Tungsten, the principle of harmonization rationalized the finding that the MVRMA intends to support grandfathering of undertakings (rather than licenses) in the same way as is supported by the CEAA. In Canadian Zinc, this principle rationalized the finding that the MVRMA intends to grandfather how the scope of an undertaking is defined by an agency in a similar way to its use in the CEAA.

Because there are only a limited number of cases to draw upon, it is difficult to draw durable conclusions about their authority and meaning. That being said, the Court of Appeal in

\footnotetext{
${ }^{102}$ De Beers at para 37.

${ }^{103}$ Ibid.
} 
Tungsten is currently the leading authority on this issue in the Northwest Territories. Moreover, it is arguable that the courts are correct to assume that Parliament is partial to harmonization, as evidenced by its use of similar procedures for environmental assessment in both statutes, its own statements regarding the MVRMA as well as the broader trend to harmonize environmental legislation between various jurisdictions in Canada.

Despite the authority of the court, the principle of harmonization, as used in these two cases, should be of limited relevance where Indigenous participation is apparent and germane to a decision of a board in the region. The limited relevance of both Tungsten and Canadian Zinc can be ascribed to the fact that neither of the cases speaks effectively to the broader issues of Indigenous participation, the origins of the MVRMA in treaties, or the impact of harmonization on participatory goals. Instead, the leading case on taking Indigenous participation into account should be De Beers, where the court illustrated that when Indigenous participation comes to the fore, courts should discourage harmonization in favour of considering the value of Indigenous perspectives on the issue at hand. The following discussion addresses these points in detail.

It is commonly acknowledged in the cases dealing with the MVRMA that the context of its adoption (i.e. contemporary treaties) reflects a process aimed at achieving political autonomy. Similarly, it is widely known that the central innovation of co-management is its incorporation of participants who can presumably represent the technical, social, and political knowledge of Indigenous peoples in the region. ${ }^{104}$ However, neither the court in Tungsten nor the court in Canadian Zinc interpreted Indigenous participation or the origins of the statute in treaties to be relevant to the construction of the Act's object. ${ }^{105}$ The decisions in Tungsten and Canadian Zinc are characterized by a highly technical analysis of the language and sentence structure of s.157.1. The approach is common to statutory interpretation. Regardless, however, of the statutory meaning adopted, the normative basis for the courts' interpretations can be sourced to their construction of the purpose and object of the legislation. Thus, the courts in both Tungsten and Canadian Zinc adopted a purposive and contextual approach to statutory interpretation. ${ }^{106}$ The court in Tungsten did note that the stated purpose of the statue was to establish boards to enable residents of the Mackenzie Valley to participate in resource management. However, it argued that the relevant purpose of the MVRMA was to grandfather existing developments in order to balance competing interests. ${ }^{107}$ Against this construction of

\footnotetext{
${ }^{104}$ Sari M. Graben, "Establishing Participation in the Mackenzie Valley Resource Management Act" (on file with author).

${ }^{105}$ Neither did the courts interpret Indigenous participation to be relevant to establishing the standard of review. For instance, the lower court in Tungsten noted that there was nothing to suggest that the Board has any particular expertise regarding the statutory interpretation issues before the court. North American Tungsten Corp. Ltd. v. Mackenzie Valley Land and Water Board [2002] NWTJ 89 at para 16.

${ }^{106}$ Tungsten, at para 21.

107 Ibid at para 24.
} 
the object of the Act, the Court of Appeal turned its attention to the specific wording of s. 157.1 and characterized it as complementary to the CEAA. ${ }^{108}$

In short, the courts did not seem to consider Indigenous participation or the origins of the MVRMA in treaties to be relevant to its interpretive task. It may be that Indigenous participation was not at issue in these cases. For example, stakeholder submissions at the board level in Tungsten were mostly made by environmental organizations, not Indigenous governments. Neither did any Indigenous government intervene in the case. Alternatively, it may be that even if there was Indigenous participation on the interpretation of the statute, the established meaning of grandfathering in legal doctrine limits its relevance. Although interestingly, both decisions reflect on the expertise of co-management boards in establishing the standard of review and find there to be no special knowledge held by the boards to warrant deference on statutory interpretation. However, irrespective of the reason, the courts in these two cases do not consider the matter of participation with any sufficiency to permit conclusions about its relevance.

Neither do the courts in either of these two cases convey any thoughts on the broader impact of harmonization on Indigenous participation. While the courts advocate harmonization, neither of them reflects on its positive or negative impacts. The effect of harmonizing the provisions can be to supplant statutory interpretation by a board that might otherwise reflect differentiated approaches to resource management. It can allow the courts to rationalize the replacement of differentiated interpretation with norms that are hard to distinguish from those of the Federal government. This rationalization is problematic in light of the MVRMA's intention to reflect Indigenous perspectives on resource management: perspectives that may be different from other regulatory schemes. However, no aspect of this debate is reflected in the decision. Instead, both Tungsten and Canadian Zinc have interpreted an intention to harmonize the meaning of the two statutes in accordance with the meaning provided by the donor legislation. The MVRMA will therefore, be interpreted in accordance with state management principles that dictate outcomes in other legislative schemes.

Importantly, the interpretive methodology used by these two courts is not out of the ordinary. Courts have long interpreted similar language in different statutes as having the same meaning and effect. However, the potential effect of harmonization is notable here because its rationalization can allow courts to divorce the potential impact of the MVRMA's participatory provisions on statutory interpretation from its own interpretation. Judicial reasoning, which assumes harmonization, can compound the effect of transplantation by limiting the import of the participatory provisions to formal procedural requirements. Rather than consider the potential substantive impact of Indigenous participation, establishing harmonization as an intention of the Federal government, can preclude that substantive impact. This preclusion

\footnotetext{
108 Ibid at para 29.
} 
results from judicial reasoning that does not turn its mind to whether statutory interpretation can be impacted by virtue of Indigenous participation. By doing so, the decisions can send a message that co-management boards should not develop the meaning of its governing legislation to reflect the local context in which it must operate. ${ }^{109}$

If lower courts applied the principle of harmonization, established in Tungsten and Canadian Zinc, to situations in which Indigenous participation is apparent or germane, it can lead to facile assumptions that undermine the central objective to promote Indigenous participation. Should Indigenous perspectives be precluded from impacting statutory interpretation then it brings into question how Indigenous participation will promote the policy objectives of comanagement. As established earlier, as a transplant, the MVRMA does not in and of itself reflect Indigenous values or perspectives on resource management. Therefore, Indigenous perspectives are meant to manifest through certain participatory provisions. However, if reasoning used in these two cases precludes participation in statutory interpretation, it becomes unclear when or how those perspectives are permitted to manifest. Instead, judicial reasoning should ask whether an interpretation of a statute, which is at odds with an agency's interpretation, has the potential effect of ignoring what impacts participation can have on regulatory output.

The decision in De Beers provides a starting point for allowing differentiated interpretations based on a Parliamentary intention for Indigenous participation. This case did not cite Tungsten. However, it can be distinguished from Tungsten for its ratio that where Indigenous participation is germane to an issue, harmonization is not appropriate. Importantly, this principle is premised on the court's construction of Parliamentary intent vis a vis the MVRMA, which is that,

Aboriginal people were intended to have meaningful input into this process. Parliament intended that potential environmental impacts and public concern be important factors for the Review Board in making decisions. Parliament also intended that the preservation of social, cultural, and economic well being of the residents of the region and the importance of conservation to the well-being and way of life of Aboriginal people be taken into account. ${ }^{110}$

In addition, the court established Parliament's intent to be the use of the Review Board's composition to balance complex and potentially conflicting factors it is mandated to take into account on environmental assessment. ${ }^{111}$

\footnotetext{
${ }^{109}$ For extensive discussion of statutory interpretation and standards of review, see Sara Blake, 'The Standard of Review Applied to the Interpretation of Statute' in Administrative Hot Topics, Best Practices: Everything You Need to Know In 2006 (Toronto, Ontario: OBA Institute of Continuing Legal Education, January 23, 2006); Marie-Helene Blais et al., eds, Standards of Review of Federal Administrative Tribunals (Markham, Ontario: LexisNexis Canada Butterworths, 2007). Also, Ruth Sullivan, Sullivan and Driedger on the Construction of Statutes, $4^{\text {th }}$ ed. (Markham, Ontario: Butterworths, 2002).

${ }^{110}$ De Beers at para 25.

${ }^{111}$ Ibid at para 26.
} 
As introduced above, the case revolved around three issues. The court's reasoning on each of the issues presented in the case reflected this construction of Parliamentary intent. For example, in relation to the first issue, ordering an environmental impact review, Charbonneau J. engaged in a somewhat technical interpretation of the word 'consideration'. However, based on the unique context of the statute's adoption, the importance of the role given to the Review Board, and the importance placed on public concern, the court rejected the submission that the meaning given to the term 'consideration' in the context of the CEAA is helpful to its interpretation. ${ }^{112}$ The court further rejected the submission that the Review Board must consider all factors in depth prior to ordering an impact assessment. Instead, Charbonneau J. stated, "On the contrary, taking into consideration this Act as a whole and the unique context of its adoption...I am of the view that the powers given to the Review Board should, wherever possible, be interpreted in a manner that gives the Review Board the flexibility it needs to carry out its broad and complex mandate." ${ }^{113}$

The court addressed the jurisdictional issues in a similar way. De Beers had submitted that the Review Board prejudged the issues, fettered its own discretion, or took into account irrelevant factors that arose in community workshops and hearings. The court noted that the Review Board's reports confirmed that community members raised many issues at these hearings. However, the court differentiated between reports by the Review Board on those submissions and the Reasons provided by the Review Board, the latter of which is where the court argued the focus of inquiry should be. Showing an understanding for how participation works, the court noted,

any process that is designed, among other things, to engage the public and seek input from various sources, has the potential of generating information and comments that are not relevant to the decision that has to be made. ${ }^{114}$

Instead of evidencing prejudgment, the court properly characterized these hearings as meaningful participation from the community and distinguished it from the Review Board's findings. ${ }^{115}$

Lastly, the court addressed the submission by De Beers that the Review Board erred in finding there to be a cause of significant public concern. While not entirely clear from the written decision of the court, it seems that De Beers had submitted that the Review Board had failed to evaluate whether the public concern expressed in community workshops was justified. The

\footnotetext{
112 Ibid at para 37.

113 Ibid at para 45.

${ }^{114}$ Ibid at para 52.

115 Ibid at para 55-56.
} 
court rejected this interpretation. Instead, it argued that the unique context within which the MVRMA was enacted and its stated purpose shows an intention that the mere existence of public concern is an important factor. It does not require the Review Board to be satisfied that concerns are insurmountable, unappeasable, or justified. ${ }^{116}$ In Charbonneau J.'s construction, the Review Board implements Indigenous participation not only through its final recommendations. It also implements participation through its power over processes developed pursuant to the MVRMA. Where those processes reflect Parliamentary intentions vis a vis Indigenous peoples, it is to be expected that they may be different than those developed in other legislative schemes.

DeBeers exemplifies a circumstance in which judicial caution should be directed at inquiring whether judicial interpretation of a statute which is at odds with an agency's interpretation has the effect of ignoring the impact of participation on statutory interpretation. Assumptions that the MVRMA can or should be used in the same manner as other Canadian jurisdictions should also consider the role of Indigenous participation in its suggested use. A solitary focus on the intention of Parliament to have the same meaning applied to both pieces of legislation permits the donor's meaning to take precedence. The effect may be to silence Indigenous perspectives.

The DeBeers case provides a starting point for allowing differentiated interpretations based on a reading of Parliamentary intention for diversity. While it is argued here that the construction of Parliamentary intention as either harmonized or differentiated is artificial, the court's reasoning reflects an understanding that Indigenous participation will not only manifest in the final recommendations of the board. It can also manifest in the way law is used and the values that use represents. This approach is illustrated by Justice Charbonneau's construction of the intention of Parliament to be the creation of a differentiated scheme for land and water use management in the Mackenzie Valley. Through this approach the court rationalized interpretive authority in the board as representative of that differentiation.

This reasoning takes the understanding of participation beyond the mere act of decisionmaking. The court's acceptance of the MVRMA as legislation that reflects the terms and values of the treaties and which reflects a different process for environmental assessment is pivotal to its approach. ${ }^{117}$ In Charbonneau J.'s construction, the board implements treaty objectives and Indigenous participation not only through its recommendations. It also implements them through its interpretative power over the meaning of the MVRMA and its impact on various stakeholders in the Mackenzie Valley. Despite a trend to harmonization, the decision of the court in De Beers indicates another more adaptive approach to transplants that warrants future analysis.

\footnotetext{
${ }^{116}$ Ibid at para 65-66.

${ }^{117}$ Exceptions which require the application of the CEAA are detailed in the MVRMA, s 116, s 130(1)(c), and 141(2)(a).
} 
All this is not to say that harmonization should never occur. It is important to note that, taken together, these cases highlight that both harmonization and difference have a foundation in the MVRMA. However, if the conflicting cases and provisions illustrate how the legislative intent of the drafters can rationalize both harmonization and differentiation, which one is correct? The most likely (and unspoken) reality which undermines either rationalization is that Parliament's intentions are probably multiple and dichotomous. In all likelihood, its drafters intended both harmonization and differentiation. As in other legislative schemes, which attempt to appease multiple and conflicting stakeholders, it was drafted to contain the possibility for difference (in accordance with treaty obligations) as well as consistency with other environmental assessment schemes (familiar and recognizable to industry-based users).

Instead, it is argued here that courts should distinguish between Parliamentary intent for harmonization against the values that underpin certain interpretations of the MVRMA. To review a board's decisions without consideration of the Indigenous perspectives contradicts the essence of the MVRMA as a legislative attempt to institutionalize Indigenous perspectives through a new method of participation. That is, while harmonization and differentiation are both very much a part of the MVRMA, they must both account for the incorporation of Indigenous perspectives and values in order to be understood as just. Consequently, the courts should be considering what role co-management boards play in achieving its participatory goals. Curtailing these perspectives is not necessarily a negative outcome. However, curtailing those perspectives without recognizing it as such seems problematic. Agencies tasked with translating local Indigenous perspectives on resource management into regulatory output can expect to produce rules, decisions, and interpretations that can be differentiated from other regimes. Seen in this light, the provisions of the MVRMA which allow for regulatory difference and the board's use of context to give direction to that difference is a use of law that interprets the MVRMA. An approach, however, that seeks to curtail based on broad rationalizations can undermine the work of agencies that attempt to represent under-represented perspectives. It undermines an understanding that interpretations can reflect Indigenous perspectives that result from participation. Those differences mean that Aboriginal participation will not only manifest in the final recommendations of the board but in the way law is used and the values that use represents.

The effect of discounting participation is to undermine the analytical significance of comanagement institutions purposefully designed to integrate Indigenous stakeholders in decision-making. While the participatory requirements outlined in the MVRMA are important, the harmonized approach described here divorces procedure from the broader policy objectives of co-management. Instead of power sharing or better resource management, participation is seen to be met where the procedural requirements of the MVRMA are met. Its effect is to use a procedural concept of participation as a legitimating process. Meeting the procedural requirements of the MVRMA is sufficient for the court to review its decisions as if participatory goals have been met. In contrast, a more complex conception of participation 
understands that stakeholder participation can alter what the regulatory output looks like and that board members play an essential role in achieving that change with their authority. In short, effective participation is a reflection of the ability of the substantive content to reflect Indigenous perspectives.

Ultimately, recognizing the MVRMA as a transplant behooves asking whether the meaning of the rules surrounding co-management should be harmonized with those of the CEAA. In contrast to understanding the MVRMA as merely meeting a particular institutional need, it is recast as law which reflects the values that were developed in one locale and which replace laws that would have otherwise been generated to reflect the social and political values of another. The cases discussed here raise the same concerns that harmonization of meaning can allow courts to ignore the context from where rules came and where they are applied. It can allow resource management rules to be treated as universal, despite significant differences in context. Rather than recognizing the assumptions in the MVRMA about such things as the value of resource management and how to talk about it, harmonization treats those assumptions as immediately applicable to Indigenous communities in the Mackenzie Valley. This is despite the fact that those assumptions were forged through a long history of social and political development that is not necessarily part of the Northern Indigenous experience. Consequently, beliefs that it can or should be used in the same manner as used in other Canadian jurisdictions should be made with caution where Indigenous participation indicates otherwise.

\section{CONCLUSION}

The discussion here has established that the substantive objectives of co-management, more effective resource management and power sharing, are not made explicit in the text of the MVRMA. Nor, as just discussed, are they made apparent from the state management principles upon which the MVRMA rests. Instead, Indigenous perspectives or traditions are intended to manifest through certain provisions that allow Indigenous participation. However, because the substantive goals of participation remain unexpressed in the MVRMA, it remains unclear to what extent these participatory initiatives may impact the regulatory output of the boards. Essentially, it remains ambiguous whether Indigenous participation 1 ) is only procedural - so that meeting the requirements of the MVRMA are sufficient to establish participation or 2) also imports the potential to alter the regulation in accordance with the substantive content of Indigenous traditions or perspectives on resource management.

Insights garnered from transnational initiatives for law reform and a series of recent Canadian cases on the MVRMA provide some cautionary insights about the effectiveness of participatory provisions in achieving co-management's objectives. The current partiality of the judiciary to harmonization indicate that despite the intention to allow Indigenous participation to impact decision-making, the courts have assumed that similarities between the CEAA and the MVRMA reveal an intention to harmonize the meaning of the two in accordance with the meaning provided by the donor legislation and its drafters. However, under the MVRMA, harmonizing 
meaning is problematic where it minimizes the impact of Indigenous participation to a procedural requirement of the statute.

This discounting of participation can have the effect of undermining the analytical significance of institutions purposefully designed to integrate Indigenous stakeholders and their viewpoints in decision-making. While procedure is most certainly essential for achieving participation, the approach adopted in Tungsten and Canadian Zinc can have the effect of divorcing the procedural from the substantive objectives of co-management. Instead, building on the approach championed in De Beers, it is more appropriate to see the MVRMA as reflecting an expectation that participation can result in values that are distinguishable from those of state management built into the MVRMA. 